\title{
Heterogeneous interplate coupling along the Nankai Trough, Japan, detected by GPS-acoustic seafloor geodetic observation
}

\author{
Yusuke Yokota ${ }^{1 *}$, Tadashi Ishikawa', Mariko Sato ${ }^{1}$, Shun-ichi Watanabe ${ }^{1}$, Hiroaki Saito ${ }^{1}$, Naoto Ujihara ${ }^{1}$, \\ Yoshihiro Matsumoto ${ }^{1}$, Shin-ichi Toyama ${ }^{1}$, Masayuki Fujita ${ }^{1}$, Tetsuichiro Yabuki ${ }^{1}$, Masashi Mochizuki ${ }^{2}$ \\ and Akira Asada ${ }^{3}$
}

\begin{abstract}
The recurring devastating earthquake that occurs in the Nankai Trough subduction zone between the Philippine Sea plate and the Eurasian plate has the potential to cause an extremely dangerous natural disaster in the foreseeable future. Many previous studies have assumed interplate-coupling ratios for this region along the trench axis using onshore geodetic data in order to understand this recursive event. However, the offshore region that has the potential to drive a devastating tsunami cannot be resolved sufficiently because the observation network is biased to the land area. Therefore, the Hydrographic and Oceanographic Department of Japan constructed a geodetic observation network on the seafloor along the Nankai Trough using a GPS-acoustic combination technique and has used it to observe seafloor crustal movements directly above the Nankai Trough subduction zone. We have set six seafloor sites and cumulated enough data to determine the displacement rate from 2006 to January 2011. Our seafloor geodetic observations at these sites revealed a heterogeneous interplate coupling that has three particular features. The fast displacement rates observed in the easternmost area indicate strong interplate coupling (>75\%) around not only the future Tokai earthquake source region but also the Paleo-Zenisu ridge. The slow displacement rates near the trench axis in the Kumano-nada Sea, a shallow part of the 1944 Tonankai earthquake source region, show a lower coupling ratio (50\% to 75\%). The slow displacement rate observed in the area shallower than the 1946 Nankaido earthquake source region off Cape Muroto-zaki reflects weakening interplate coupling (about 50\%) probably due to a subducting seamount. Our observations above the subducting ridge and seamount indicate that the effect of a subducting seamount on an interplate-coupling region depends on various conditions such as the geometry of the seamount and the friction parameters on the plate boundary.
\end{abstract}

Keywords: Seafloor geodetic observation; Nankai Trough; Interplate coupling; Seamount subduction

\section{Background}

\section{Nankai trough subduction zone}

In southwestern Japan, the oceanic Philippine Sea plate is subducting beneath the continental Eurasian plate northwestward along the Nankai Trough. In this region, interplate magnitude-8-class earthquakes have been documented with an average recurrence time of about 100 years (e.g., Ando 1975) due to this plate motion. The most recent events are the 1944 Tonankai (M7.9)

\footnotetext{
* Correspondence: eisei@jodc.go.jp

'Hydrographic and Oceanographic Department, Japan Coast Guard, 2-5-18

Aomi, Koto-ku, Tokyo 135-0064, Japan

Full list of author information is available at the end of the article
}

and the 1946 Nankaido (M8.0) earthquakes. Thus, the next magnitude-8-class earthquake is predicted in the near future.

We analyzed the coseismic slip distributions of the 1944 and 1946 events using triangulation and leveling survey records (e.g., Sagiya and Thacher 1999 and Ito and Hashimoto 2004) and tsunami records (e.g., Tanioka and Satake 2001 and Baba and Cummins 2005). To understand the next disastrous event in advance, several research groups also analyzed the interseismic slip deficit for recent years using onshore global positioning systems (GPS) data (e.g., Nishimura and Hashimoto 2006 and Loveless and Meade 2010). The onshore geodetic 
data do not have the power to resolve the offshore region as indicated in Yoshioka and Matsuoka (2013) (Figure 1). They pointed out the importance of seafloor geodetic observations for revealing the offshore region along the Nankai Trough.

\section{Seafloor geodetic observation using a GPS-acoustic combination technique}

In order to monitor seafloor crustal movements around the offshore plate boundary, the Hydrographic and Oceanographic Department of Japan (JHOD) has been carrying out seafloor geodetic observations using a GPSacoustic combination technique on the landward side of the major trenches around Japan. Our past observations near the Japan Trench provided great advantage in understanding the 2005 Off-Miyagi Prefecture earthquake
(M7.2) (e.g., Matsumoto et al. 2006 and Sato et al. 2011b), the 2011 Tohoku-oki earthquake (M9.0) (e.g., Sato et al. 2011a and Sato et al. 2013b), and others. Important observations have also been made by other research groups in Japan such as Tohoku University (e.g., Kido et al. 2006 and Kido et al. 2011) and Nagoya University (e.g., Tadokoro et al. 2012 and Yasuda et al. 2014).

In the Nankai Trough region, we were operating six seafloor sites along the trench axis at about 50 to $100 \mathrm{~km}$ intervals (Figure 1 and Table 1) before the 2011 Tohoku-oki earthquake. In this paper, we report displacement rates on the seafloor surface and discuss interplate coupling along the Nankai Trough during the period before the 2011 Tohoku-oki earthquake and, thus, unaffected by postseismic effects from this enormous event. Our observations directly revealed an

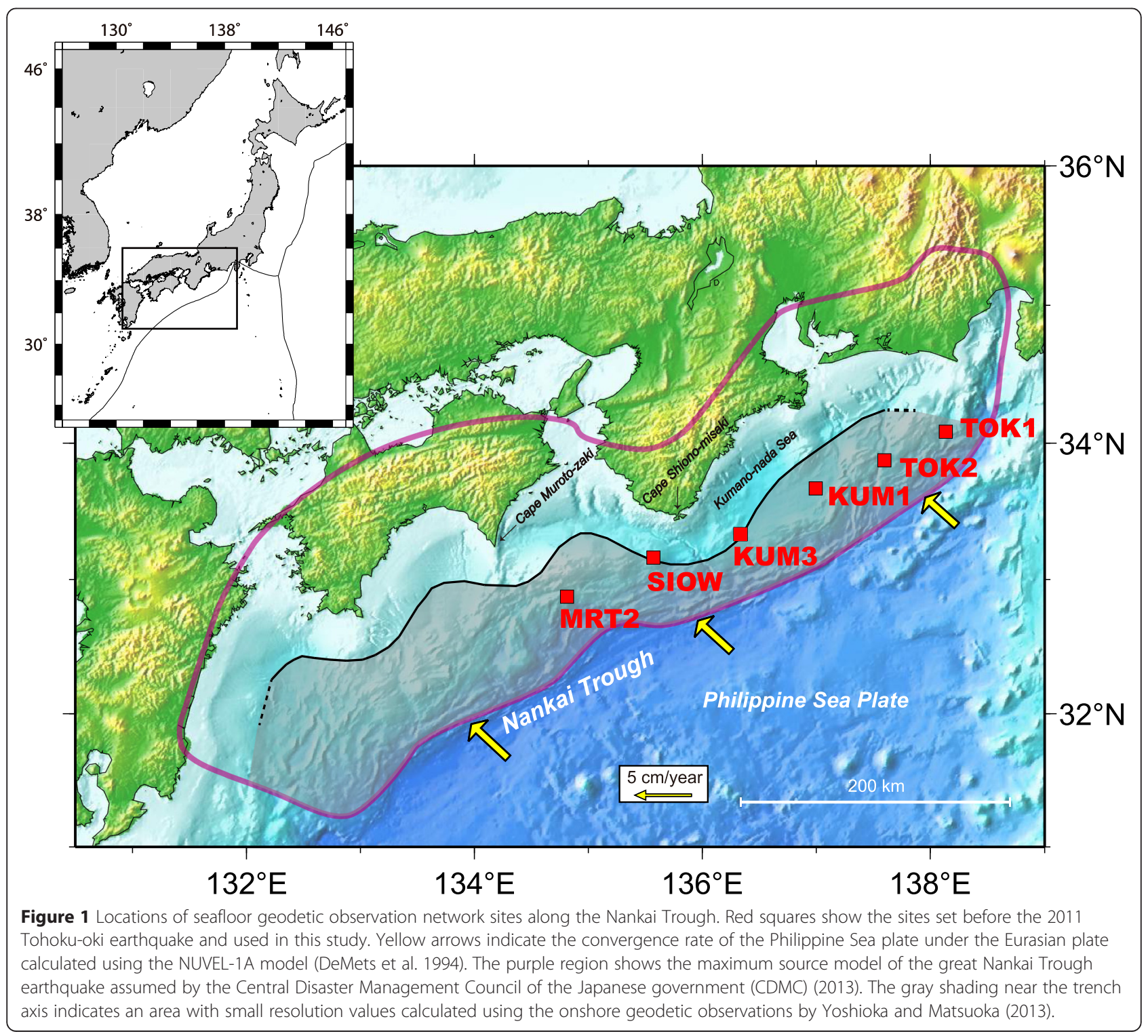


Table 1 Positions of seafloor sites

\begin{tabular}{llll}
\hline Site name & Latitude (degree) & Longitude (degree) & Height $(\mathbf{m})$ \\
\hline TOK1 & $34.08231 \mathrm{~N}$ & $138.13395 \mathrm{E}$ & $-2,374$ \\
TOK2 & $33.87698 \mathrm{~N}$ & $137.59508 \mathrm{E}$ & $-1,524$ \\
KUM1 & $33.67026 \mathrm{~N}$ & $136.99558 \mathrm{E}$ & $-1,957$ \\
KUM3 & $33.33287 \mathrm{~N}$ & $136.34232 \mathrm{E}$ & $-1,957$ \\
SIOW & $33.16056 \mathrm{~N}$ & $135.57229 \mathrm{E}$ & $-1,524$ \\
MRT2 & $32.87264 \mathrm{~N}$ & $134.81463 \mathrm{E}$ & $-1,402$ \\
\hline
\end{tabular}

uneven accumulation of interplate coupling along the Nankai Trough.

\section{Methods}

\section{Measurement system}

The GPS-acoustic combination technique was developed to detect seafloor displacements with an accuracy of a few (2 to 3) centimeters (e.g., Spiess et al. 1998 and Asada and Yabuki 2001). In Japan, our group first succeeded in detecting seafloor movements caused by plate convergence at the Japan Trench (Fujita et al. 2006) and has been deploying a seafloor observation network since 2000.

A schematic picture of our seafloor geodetic observation system is shown in Figure 2. This system consists of a seafloor unit with four acoustic mirror-type transponders and an on-board unit with a GPS antenna/receiver, an undersea acoustic transducer, and a dynamic motion sensor. The onboard acoustic transducers were mounted at the stern of survey vessels using an $8 \mathrm{~m}$-long pole before 2007. We used to carry out surveys using a drifting observation method with the pole system before 2007, as shown in Figure 2a. We improved the observations by

\section{(a) Pole system}

(b) Hull-mounted system

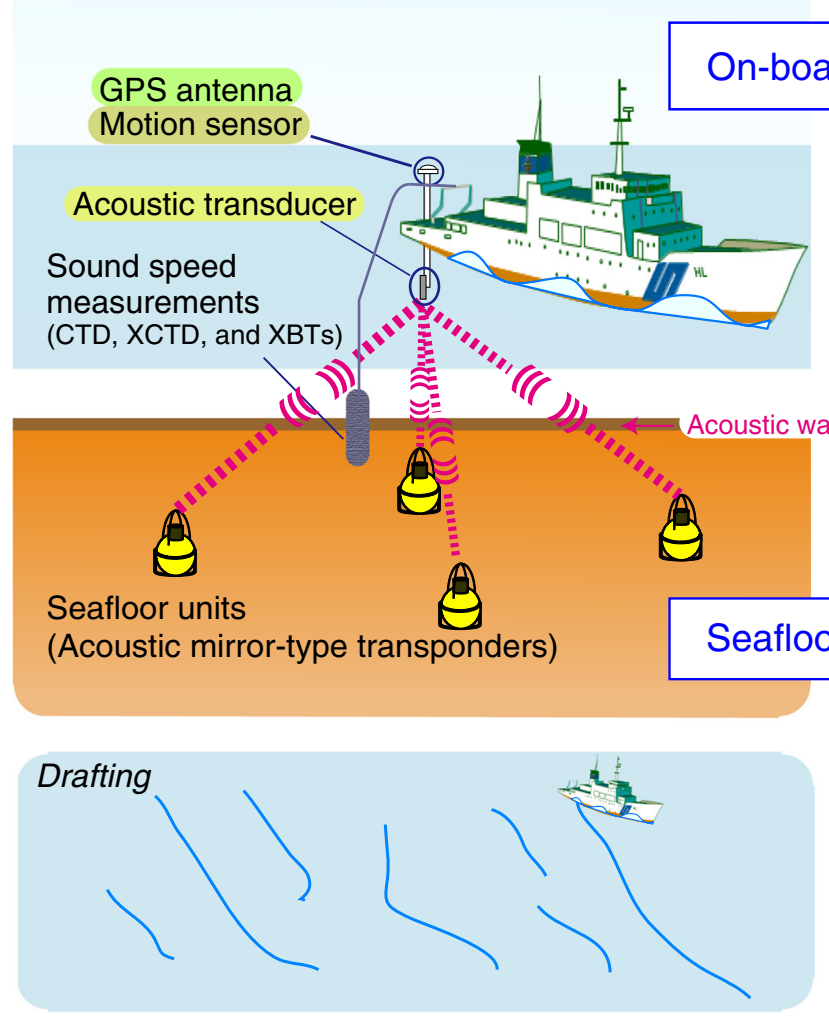

\section{Unit}
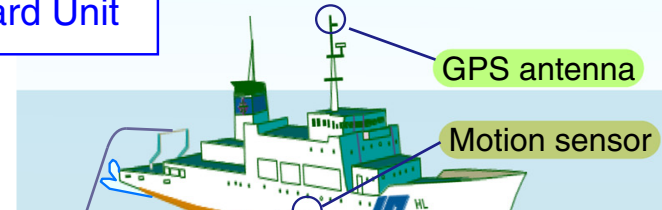
measurements (CTD, XCTD, and XBTs) 
switching to a line-controlled sailing observation method with a hull-mounted system after 2008 as shown in Figure 2b. Detail methodologies are introduced in Sato et al. (2013a).

The system measures ranges from the on-board transducer to the seafloor acoustic transponders through roundtrip acoustic travel times. Acoustic velocity profiles in the seawater are necessary to transform travel time into range. These are obtained using temperature and salinity profilers (conductivity temperature depth profiler (CTD), expendable conductivity temperature depth profiler (XCTD), and expendable bathy thermographs (XBTs)) every several hours. Kinematic GPS data are simultaneously gathered to determine the absolute position of the survey vessel. Attitude data on the survey vessel are also acquired on board by a dynamic motion sensor to determine the coordinates of the on-board transducer relative to those of the GPS antenna.

\section{Analytical approach}

The data analysis was done in three parts. First, we obtained the range between the on-board transducer and the seafloor transponder using a process that correlates measured acoustic wave data and velocity profiles. Second, the consecutive absolute positions of the GPS antenna on the vessel were determined by kinematic GPS analysis. Third, the position of the seafloor transponder was determined using a linearized inversion method based on a least squares formulation combining the results from prior analyses.

In the early stages of our observations, we performed this inversion analysis constrained by the height of the grouped transponders over all epochs (e.g., Fujita et al. 2006). The present analysis was constrained by the positional relationship of the grouped transponders for all epochs (e.g., Watanabe et al. 2014). The newer method was developed by Matsumoto et al. (2008) (Figure 3). To stabilize the estimates, over 5,000 shots of acoustic wave data per site were required for each observation epoch. We spent approximately $24 \mathrm{~h}$ performing an observation. More details on the analytical methodology are presented in Fujita et al. (2006), Matsumoto et al. (2008), Sato et al. (2013a), and Watanabe et al. (2014).

\section{Results and discussion \\ Observation results}

Our seafloor sites along the Nankai Trough are located on the offshore region that is predicted by the Central Disaster Management Council of the Japanese government $(\mathrm{CDMC})$ to undergo the next great Nankai Trough earthquake (CDMC 2013) (available at http://www. bousai.go.jp/jishin/nankai/taisaku/pdf/1_1.pdf, in Japanese) (Figure 1). From the eastern side, sites TOK1, TOK2, KUM1, KUM3, SIOW, and MRT2 were set along the trench axis at 50 to $100 \mathrm{~km}$ intervals. TOK1 is located closest to the trench axis.

The observations began with site KUM1 in November 2000, with the other five sites being set between 2001 and 2004. They have been operating steadily since 2006 . Here, we show observations before the 2011 Tohoku-oki earthquake. We carried out eight to ten observation campaigns in the period between 2006 and January 2011.

Figure 4 shows the time series of the estimated horizontal coordinates of these six sites. Each circle represents the coordinates of seafloor transponders for each epoch after 2006 relative to their locations in the first campaign. The positions are presented with respect to the stable part of the Eurasian plate, based on the

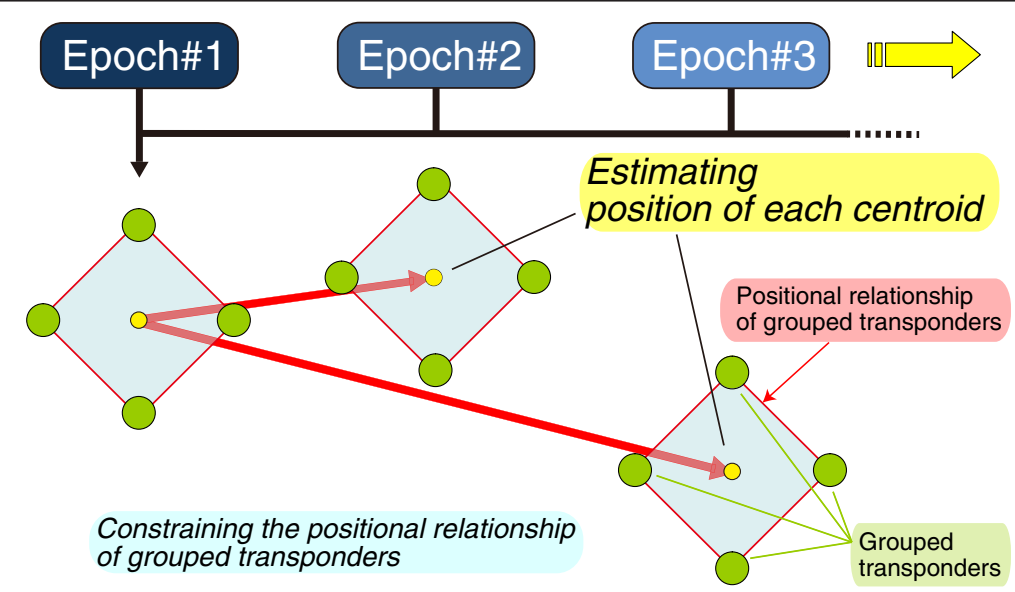

Figure 3 Schematic pictures of the estimation of seafloor positions. The positions were analyzed using the method developed by Matsumoto et al. (2008). In this analysis, we estimated the position (yellow circle) of the centroid of the grouped transponders (green circles) for each epoch, constrained by the positional relationship of the grouped transponders (red diamonds) in all epochs. 

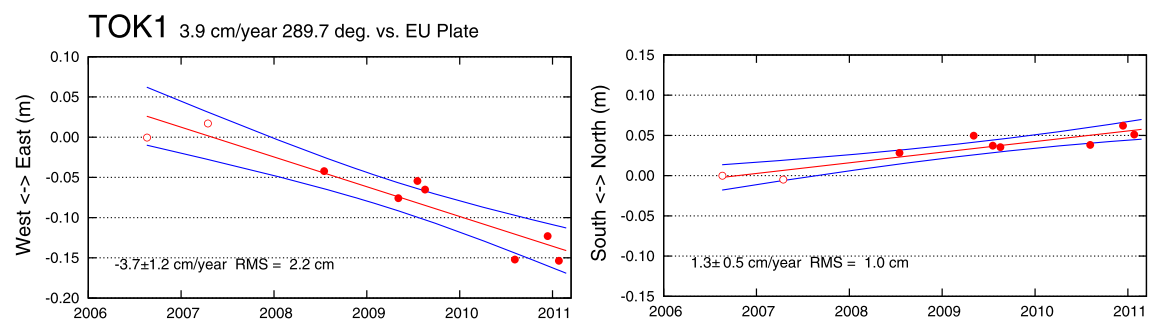

TOK2 $5.1 \mathrm{~cm} / \mathrm{year} 289.6 \mathrm{deg}$. vs. EU Plate
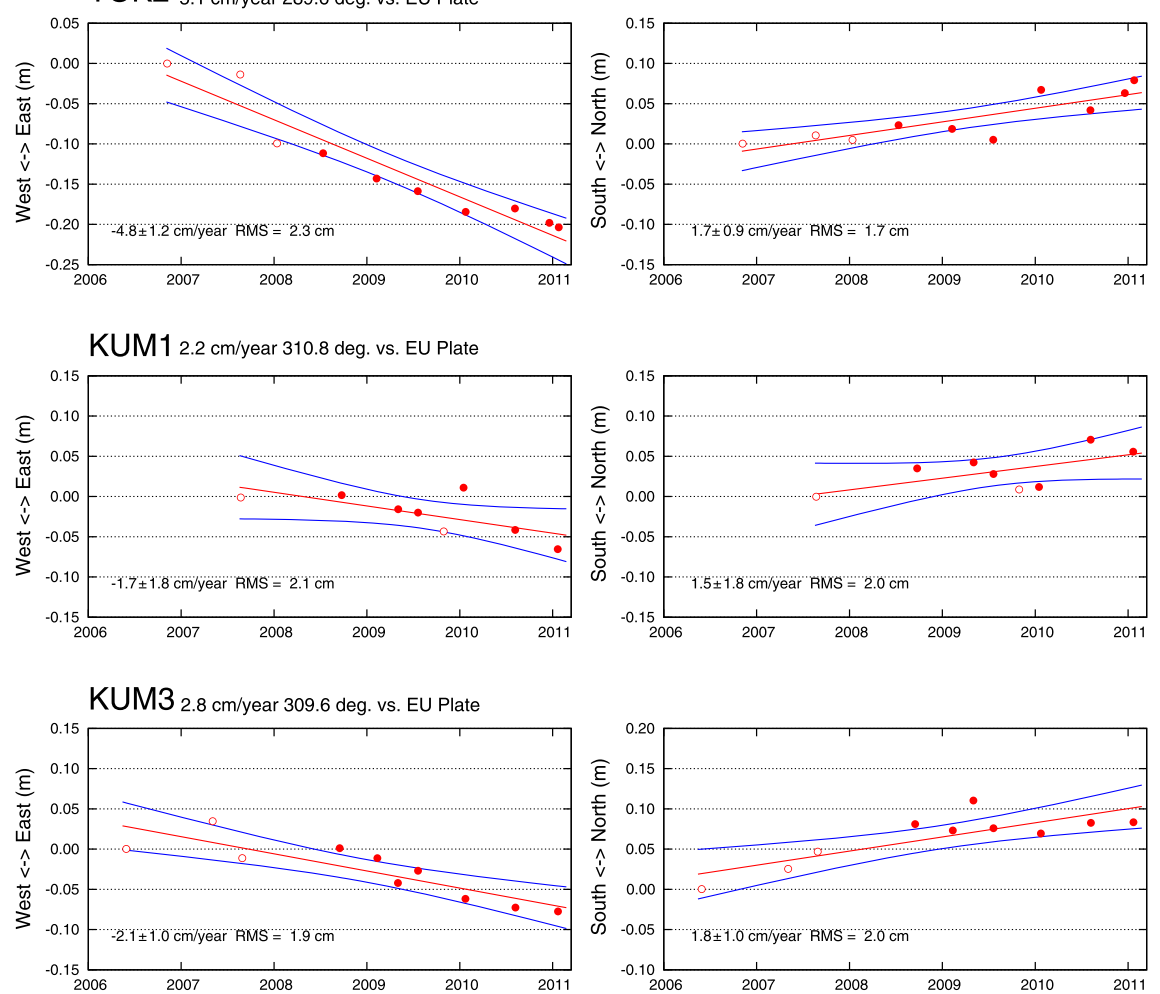

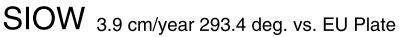
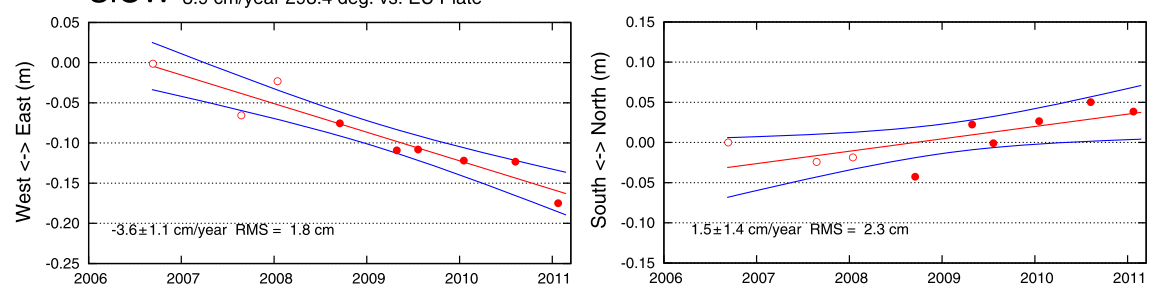

MRT2 $2.6 \mathrm{~cm} /$ year 285.0 deg. vs. EU Plate
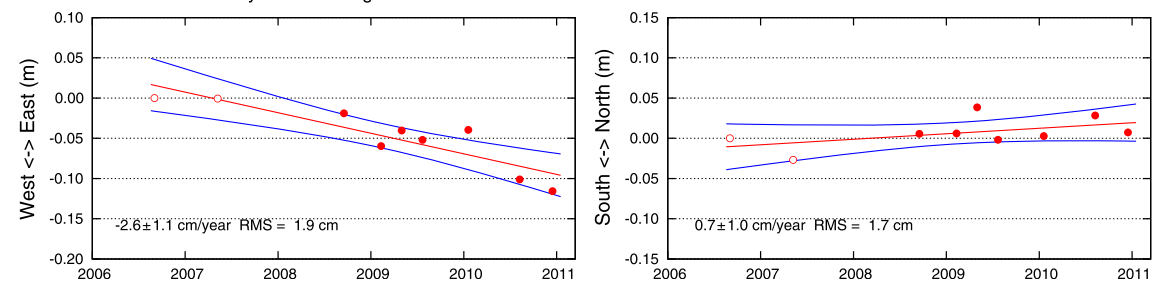

Figure 4 (See legend on next page.) 
(See figure on previous page.)

Figure 4 Time series in east-west (left column) and north-south (right column) displacements. These data were obtained at the six seafloor sites TOK1, TOK2, KUM1, KUM3, SIOW, and MRT2 for the period from 2006 to January 2011. The position reference is the Eurasian plate. The open and solid red circles indicate results from drafting observations and results from sailing observations, respectively. The linear trends and the $95 \%$ two-sided confidence intervals are shown with red and blue lines, respectively.

NUVEL-1A velocity (DeMets et al. 1994). The data are summarized in Tables 2 and 3. Reference frame in Table 2 is ITRF2005 (Altamimi et al. 2007).

\section{Seafloor displacement rates}

Figure 4 also presents linear trends fitted to these time series, which gave us the offshore velocity fields with the 95\% two-sided confidence intervals indicated by the blue hyperbolic lines. All the sites moved at stable displacement rates in the northwestward direction. Because no large earthquake occurred in this offshore region after the 2004 off-the-Kii-Peninsula earthquakes $(M \sim 7)$, these movements reflect strain accumulation processes due to the Philippine Sea plate subduction under the upper Eurasian plate.

The estimated horizontal seafloor displacement rates are exhibited by arrows in Figure 5. The ellipses indicate the 2sigma errors. The slowest and fastest velocities, 2.2 and $5.1 \mathrm{~cm} /$ year, were observed at KUM1 and TOK2, respectively, though the error ellipse of KUM1 is larger than that of the other sites because of its shorter observation period.

Figure 5 also presents the onshore velocity fields observed at GEONET stations operated by the Geospatial Information Authority of Japan (GSI) (Sagiya et al. 2000) for comparison. These onshore displacement rates were derived using the averages between March 2006 and February 2011 so as to match to our observation period.

Our seafloor observation results present uneven offshore velocity fields along the Nankai Trough. In particular, the 2 to $3 \mathrm{~cm} /$ year displacement rates at KUM1, KUM3, and MRT2 are slower than those of adjacent seafloor sites. In addition, the rates at KUM3 and MRT2 are slower than those of nearby onshore GPS stations.

The displacement rate at KUM1 is smaller than that at TOK2 (95\% confidence level (CL)). Similarly, the displacement rates at KUM3 and MRT2 are smaller than those at SIOW (95\% CL and 90\% CL) and the onshore 'Kushimoto' (99.99\% CL) and 'Muroto-4' (99.99\% CL) GPS stations as shown in Figure 6. Because the relative velocity between the Eurasian plate and the Philippine Sea plate is approximately 4 to $5 \mathrm{~cm} /$ year (e.g., Seno et al. 1993 and DeMets et al. 1994), the plate boundary beneath these three offshore sites does not have high interplate-coupling ratios $(<75 \%)$. Each observation is discussed in more detail from the eastern side below.

\section{Tokai region}

The direction and magnitude of the displacement rate at site TOK1 are approximately consistent with those of nearby onshore stations. In this easternmost plate boundary region beneath TOK 1 , no major earthquake has occurred in the past 160 years since the last historical earthquake in 1854 (Ando 1975). The CDMC (2013) therefore hypothesized that this will likely be the area of the next large event, the future Tokai earthquake (orange region in Figure 5). Our seafloor observations also confirm a high-coupling ratio $(>75 \%)$ in this region near the trench axis.

The displacement rate of the next site (TOK2) is larger than not only those of nearby onshore and adjacent offshore sites but also the subducting plate velocity calculated on the basis of the NUVEL-1A model. This is possibly due to the Izu microplate (e.g., Sagiya 1999) and the spray fault along the Nankai Trough (e.g., Park et al. 2002). This observation provides evidence for almost full coupling in this interplate region, though TOK2 was not located in the source region of the future Tokai earthquake. This region also has the potential to produce a large earthquake, similar to the region around TOK1.

\section{Tonankai region}

The western side of the future Tokai earthquake source region is the location of the 1944 Tonankai earthquake. Baba and Cummins (2005) estimated the slip distribution (blue contour in Figure 5) using tsunami data. Since the tsunami data used have resolving power in the area near the trench axis, along with the seafloor geodetic data, this offshore slip distribution is reliable and can be compared with the seafloor displacement rates.

The seafloor geodetic sites operated by Nagoya University (Tadokoro et al. 2012) are located on the north side of our seafloor sites in the Kumano-nada Sea (KUM1 and KUM3) (Figure 5). Those seafloor sites moved slower than TOK2, like our result at KUM1, and faster than nearby onshore GPS stations.

Our result at KUM3 differs from Nagoya University's results. The displacement rate at KUM3 is smaller than the nearby 'Kushimoto' GPS station (99.99\% CL), and its direction is comparatively clockwise because of a smaller westward component and a larger northward component than at 'Kushimoto' (99.99\% CL) as shown in Figure 6. If the coupling ratio of this interplate region beneath KUM3 was the same as in the north deep region beneath Nagoya University's seafloor sites, KUM3 should move faster since it is closer to the plate boundary. Therefore, the coupling ratio is believed to be lower (50\% to $75 \%$ ) there than in the north region beneath the Kumano-nada Sea. This is consistent 
Table 2 Estimated relative site positions

\begin{tabular}{|c|c|c|c|c|c|c|c|c|}
\hline Epoch (year) & Eastward (m) & Northward $(\mathrm{m})$ & \multirow{2}{*}{\multicolumn{2}{|c|}{$\begin{array}{l}2008.036^{a} \\
2008.707\end{array}$}} & \multicolumn{2}{|c|}{0.005} & & -0.039 \\
\hline TOK1 & & & & & \multicolumn{3}{|c|}{-0.034} & -0.074 \\
\hline $2006.630^{a}$ & 0.000 & 0.000 & \multicolumn{2}{|c|}{2009.323} & \multicolumn{3}{|c|}{-0.055} & -0.018 \\
\hline $2007.285^{a}$ & 0.030 & -0.015 & \multicolumn{2}{|c|}{2009.553} & \multicolumn{3}{|c|}{-0.049} & -0.045 \\
\hline 2008.537 & -0.004 & -0.001 & \multicolumn{2}{|c|}{2010.047} & \multicolumn{3}{|c|}{-0.053} & -0.025 \\
\hline 2009.340 & -0.022 & 0.008 & \multicolumn{2}{|c|}{2010.603} & \multicolumn{3}{|c|}{-0.043} & -0.010 \\
\hline 2009.545 & 0.004 & -0.008 & \multicolumn{2}{|c|}{2011.063} & \multicolumn{3}{|c|}{-0.085} & -0.029 \\
\hline 2009.627 & -0.005 & -0.011 & \multicolumn{5}{|l|}{ MRT2 } & \\
\hline 2010.595 & -0.073 & -0.023 & \multicolumn{2}{|c|}{$2006.666^{a}$} & \multicolumn{3}{|c|}{0.000} & 0.000 \\
\hline 2010.948 & -0.037 & -0.005 & \multicolumn{2}{|c|}{$2007.348^{a}$} & \multicolumn{3}{|c|}{0.013} & -0.037 \\
\hline $2011.068^{b}$ & -0.066 & -0.018 & \multicolumn{2}{|c|}{2008.707} & \multicolumn{3}{|c|}{0.023} & -0.026 \\
\hline TOK2 & & & \multicolumn{2}{|c|}{2009.110} & \multicolumn{3}{|c|}{-0.010} & -0.031 \\
\hline $2006.847^{a}$ & 0.000 & 0.000 & 2009.3 & & 0.0 & & & -0.002 \\
\hline $2007.633^{a}$ & 0.002 & -0.002 & 2009.5 & & 0.0 & & & -0.046 \\
\hline $2008.030^{a}$ & -0.076 & -0.014 & 2010.0 & & 0.0 & & & -0.049 \\
\hline 2008.526 & -0.078 & -0.003 & 2010.6 & & & 021 & & -0.031 \\
\hline 2009.104 & -0.098 & -0.017 & 2010.9 & & & 028 & & -0.058 \\
\hline 2009.548 & -0.105 & -0.037 & Referen & frame is 1 & FF2005 (Alta & imi et a & 7). ${ }^{\mathrm{E} E p o}$ & th drafting \\
\hline 2010.063 & -0.120 & 0.017 & observa & tions. ${ }^{\mathrm{b}} \mathrm{Re}$ & vely unreliabl & e due to I & lata. & \\
\hline 2010.595 & -0.106 & -0.017 & & & & & & \\
\hline 2010.964 & -0.116 & -0.001 & with & the 1944 & Tonankai & earthq & ke sour & region, which \\
\hline 2011.066 & -0.122 & 0.015 & $\begin{array}{l}\text { has a } \\
\text { differ }\end{array}$ & $\begin{array}{l}\text { peak slip } \\
\text { nt from }\end{array}$ & $\begin{array}{l}\text { region in } \\
\text { the east }\end{array}$ & $\begin{array}{l}\text { the de } \\
\text { ernmos }\end{array}$ & $\begin{array}{l}\text { Side. } 1 \\
\text { offshore }\end{array}$ & $\begin{array}{l}\text { se features are } \\
\text { egion around }\end{array}$ \\
\hline KUM1 & & & TOK & and $\mathrm{TO}$ & K2. & & & \\
\hline $2007.638^{a}$ & 0.000 & 0.000 & & & & & & \\
\hline 2008.726 & 0.025 & 0.018 & Nank & ido regic & & & & \\
\hline 2009.337 & 0.019 & 0.017 & The & bservati & on for th & e two & sternm & t sites SIOW \\
\hline 2009.551 & 0.019 & -0.001 & and $\Lambda$ & 4RT2 col & itrast with & each & er. The & sites are both \\
\hline $2009.827^{\mathrm{ab}}$ & 0.002 & -0.025 & gion & estimate & $d$ by Bab & a and & ummin & \\
\hline 2010.041 & 0.060 & -0.025 & conto & ur in Fig & ure 5). Tl & ne disp & ement & of SIOW is \\
\hline 2010.597 & 0.019 & 0.025 & simila & $r$ to neal & by onshor & e data & m Cap & Shiono-misaki \\
\hline 2011.055 & 0.004 & 0.003 & and & uggests & that the & interpla & region & round SIOW \\
\hline KUM3 & & & has a & high-cou & pling rati & $(>75 \%$ & On the & ther hand, the \\
\hline $2006.405^{a}$ & 0.000 & 0.000 & displa & cement & rate at $M$ & RT2 is & learly s & aller than the \\
\hline $2007.337^{a}$ & 0.053 & 0.011 & $(99.9$ & $\%$ CL), & as show & $n$ in & $\begin{array}{l}\text { o-zaki, } \\
\text { gure } 6\end{array}$ & $\begin{array}{l}\text {., } \\
\text { Although theto-4 }\end{array}$ \\
\hline $2007.655^{a}$ & 0.014 & 0.027 & & & & & & \\
\hline 2008.704 & 0.047 & 0.046 & & & & & & \\
\hline 2009.112 & 0.043 & 0.032 & $\begin{array}{l}\text { Table } \\
\text { comp }\end{array}$ & $\begin{array}{l}3 \text { Veloci } \\
\text { onent va }\end{array}$ & $\begin{array}{l}\text { ies with } r \\
\text { riances an }\end{array}$ & d covar & $\begin{array}{l}\text { the Eu } \\
\text { ices }\end{array}$ & plate with \\
\hline 2009.334 & 0.017 & 0.065 & Site & Velocity & $\mathrm{cm} /$ year) & Varianc & ind Cove & nce $\left((\mathrm{cm} / \text { year })^{2}\right)$ \\
\hline 2009.551 & 0.036 & 0.028 & name & East $\left(V_{e}\right)$ & North $\left(V_{n}\right)$ & $\mathrm{V}\left(V_{e}\right)$ & $\mathrm{V}\left(V_{n}\right)$ & $\operatorname{Cov}\left(V_{e}, V_{n}\right)$ \\
\hline 2010.060 & 0.011 & 0.013 & $\overline{\text { TOK1 }}$ & -3.7 & 1.3 & 0.25 & 0.05 & 0.02 \\
\hline 2010.600 & 0.011 & 0.018 & TOK2 & -4.8 & 1.7 & 0.27 & 0.14 & 0.06 \\
\hline 2011.058 & -0.037 & 0.001 & KUM1 & -1.7 & 1.5 & 0.53 & 0.52 & -0.11 \\
\hline SIOW & & & KUM3 & -2.1 & 1.8 & 0.19 & 0.20 & 0.06 \\
\hline $2006.690^{\mathrm{ab}}$ & 0.000 & 0.000 & SIOW & -3.6 & 1.5 & 0.21 & 0.33 & 0.03 \\
\hline $2007.644^{a}$ & -0.045 & -0.039 & MRT2 & -2.6 & 0.7 & 0.23 & 0.18 & -0.01 \\
\hline
\end{tabular}

Table 2 Estimated relative site positions (Continued)

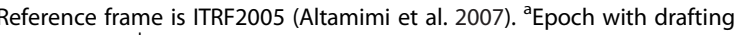

with the 1944 Tonankai earthquake source region, which has a peak slip region in the deep side. These features are different from the easternmost offshore region around TK1 and TOK2.

\section{Nankaido region}

The observation for the two westernmost sites SIOW and MRT2 contrast with each other. These sites are both located near the 1946 Nankaido earthquake source region estimated by Baba and Cummins (2005) (green contour in Figure 5). The displacement rate of SIOW is similar to nearby onshore data from Cape Shiono-misaki and suggests that the interplate region around SIOW onshore data from Cape Muroto-zaki, e.g., 'Muroto-4' (99.99\% CL), as shown in Figure 6. Although the

Table 3 Velocities with respect to the Eurasian plate with component variances and covariances 


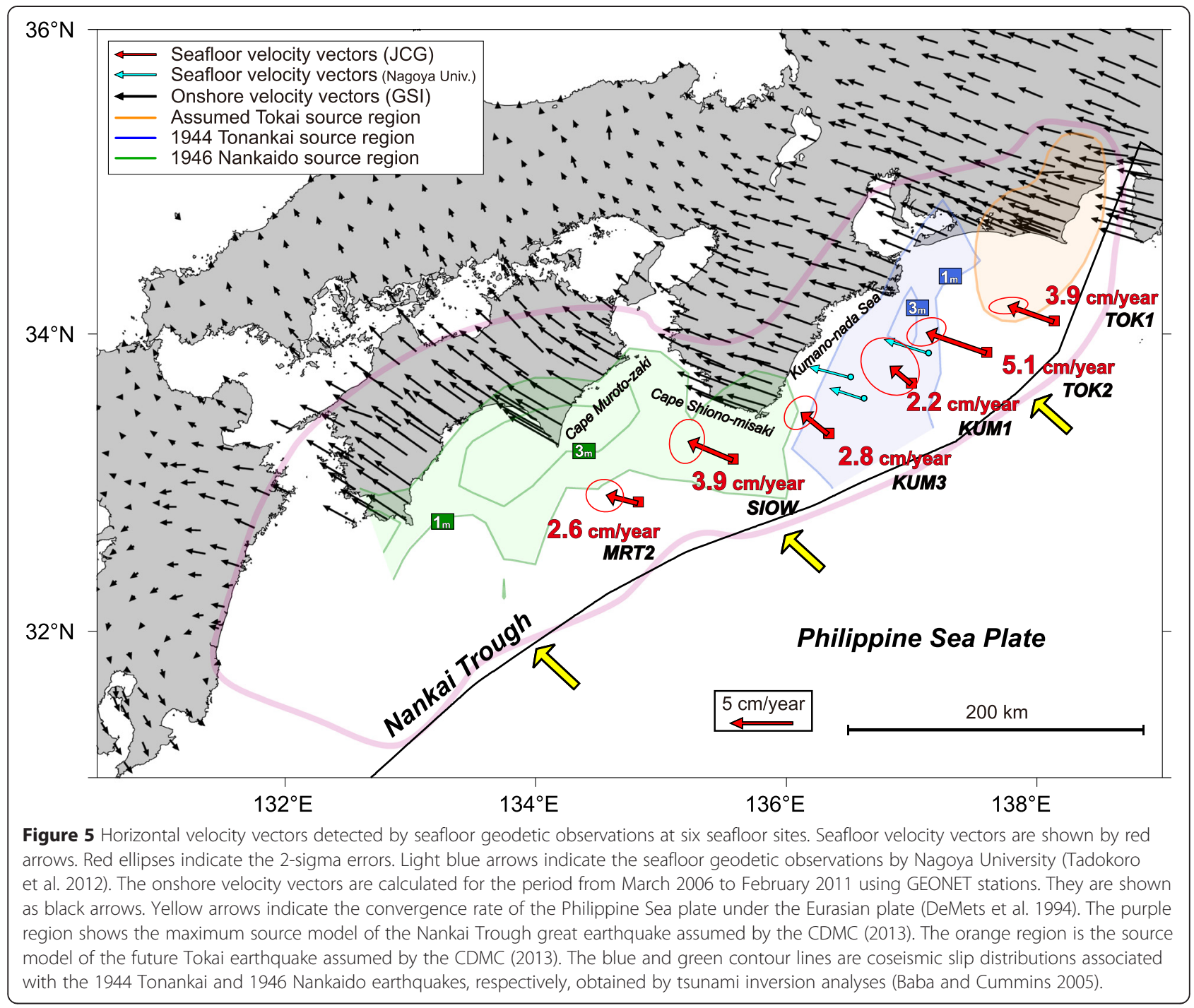

direction of SIOW's velocity vector is similar to those of onshore stations nearby, MRT2 differs in a counterclockwise fashion due to a smaller northward component than at 'Muroto-4' (99.99\% CL). The movement at MRT2 is inconsistent with the onshore geodetic observations, suggesting the presence of a weak interplate-coupling region (about 50\%) located off Cape Muroto-zaki. This is consistent with the 1946 Nankaido earthquake source region, which has a peak slip region in the deep side.

\section{Relationship with subducting seamount and ridge}

In the interplate region beneath TOK1 and TOK2, the Paleo-Zenisu ridge was detected by seismic refraction studies (Kodaira et al. 2003 and Park et al. 2003) (light blue polygon in Figure 7). These and several other studies (e.g., Kodaira et al. 2000 and Duan 2012) interpreted that a subducting seamount increases the normal stress and makes a locally strong coupling region. On the other hand, other seismic surveys (Ranero and von
Huene 2000, Bangs et al. 2006, and Mochizuki et al. 2008) and a laboratory study (Dominguez et al. 2000) suggested that interplate coupling is weak on a subducting seamount due to elevated pore pressure. Therefore, the effect of a subducting seamount on an interplatecoupling state is now being debated. Our observations at TOK1 and TOK2 suggest the presence of strong interplate coupling around the Paleo-Zenisu ridge, consistent with the strengthening effect proposed by the former studies.

On the interplate boundary beneath MRT2, the seismic refraction study detected a subducting seamount (Kodaira et al. 2000) (light blue ellipse in Figure 7). The positional relationship between this seamount and the weak interplatecoupling region suggested by our seafloor observations at MRT2 suggests the possibility that the weakening effect proposed by the latter studies is at work.

Therefore, the Paleo-Zenisu ridge and the subducting seamount located off Cape Muroto-zaki have different 


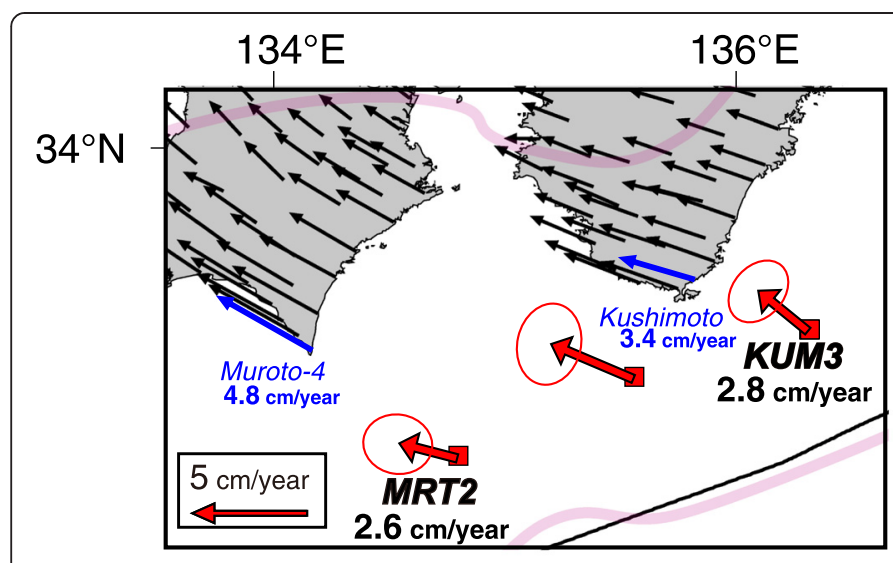

KUM3 - 'Kushimoto'
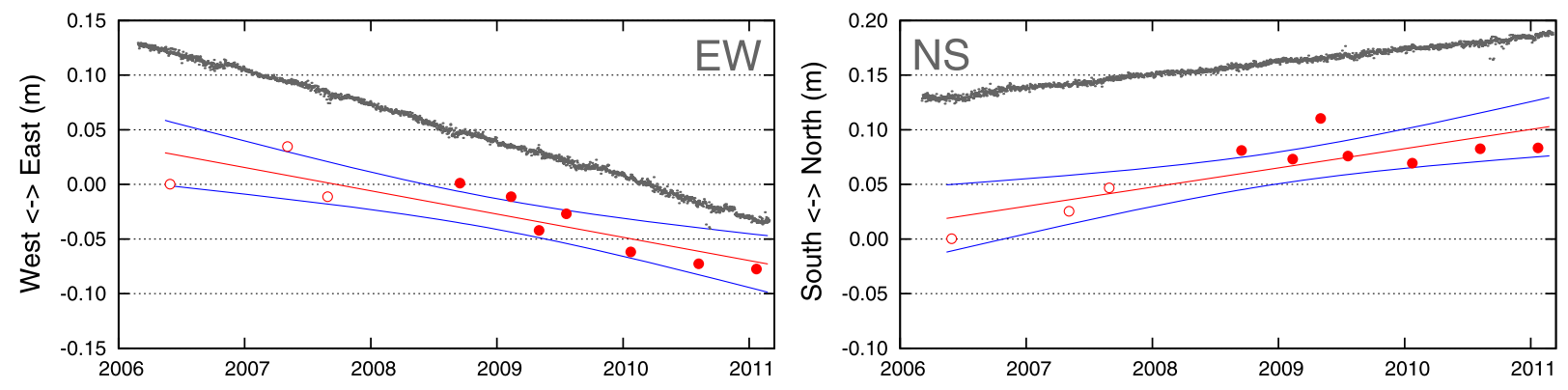

MRT2 - 'Muroto-4'
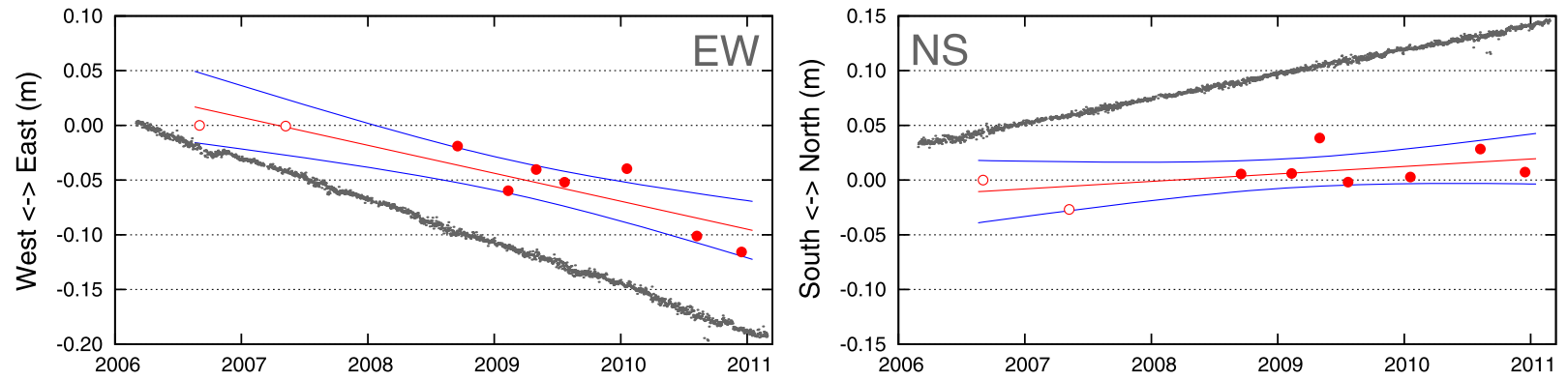

Figure 6 Comparisons of seafloor and onshore time series in east-west and north-south displacements. Time series of sites KUM3 and MRT2 compared with nearby onshore GPS data. Gray dots indicate the time series in the horizontal coordinates of the onshore 'Kushimoto' and 'Muroto-4' GPS station. The position reference is the Eurasian plate.

effects on interplate coupling. This indicates that the effect of a subducting seamount for a plate boundary differs according to various conditions, e.g., the height and width of the seamount, temperature and pressure on the plate boundary, physical properties, and convergence rate. Although the clearest difference between the Paleo-Zenisu ridge and the Muroto-zaki subducting seamount is their breadth in the east-west direction, it is difficult to identify that as the cause of the differing effects on interplate coupling because there are other unknown conditions. Recent numerical simulation studies also offer a similar suggestion (Yang et al. 2012, 2013).
They point out that the effect of a subducting seamount varies complicatedly depending on the friction parameters, the depth, and the shape.

\section{Conclusions}

We have presented the results of seafloor geodetic observations conducted over about 5 years along the Nankai Trough and found the heterogeneous interplate coupling near the trough axis to have the following features. A strong coupling region is located in the easternmost interplate region around TOK1 above the Paleo-Zenisu ridge that is hypothesized to 


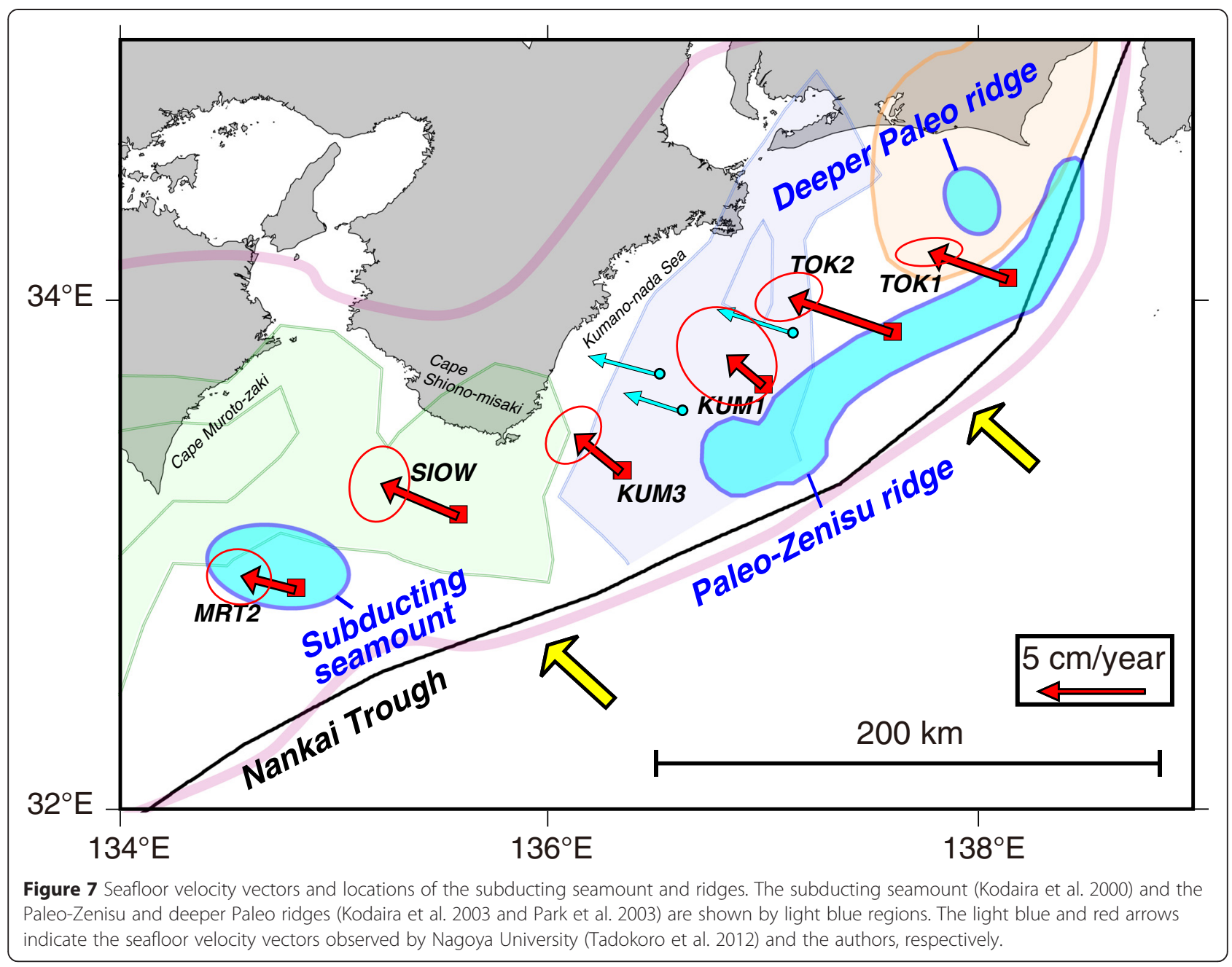

be the source area of the future Tokai earthquake. This strong coupling region is believed extend to the southwest around TOK2. A shallow interplate region around KUM1 and KUM3 does not show a full coupling ratio, which is consistent with the 1944 Tonankai earthquake source region estimated using tsunami data. In the westernmost region, the slow displacement rate observed at MRT2 reflects weak interplate coupling, probably due to the subducting seamount off Cape Muroto-zaki. Our observations above the subducting ridge and seamount indicate that the effect of a subducting seamount on interplate-coupling region differs depending on various conditions.

As above, our seafloor geodetic observations suggested a complication of the interplate coupling on the assumed maximum source model of the Nankai Trough great earthquake. However, the blank offshore region on the west side of MRT2 has still not been revealed. In order to expand the seafloor geodetic observation network to this blank region and interpolate other blank regions, nine new seafloor sites were deployed in addition to the six existing sites after November 2011. These new sites will deliver useful information for discussing the earthquake model and disaster prevention in more detail.

\section{Abbreviations}

CDMC: the Central Disaster Management Council of the Japanese

government; CL: confidence level; CTD: conductivity temperature depth profiler; GPS: global positioning system; GSI: Geospatial Information Authority of Japan; JHOD: Hydrographic and Oceanographic Department of Japan; XBT: expendable bathy thermograph; XCTD: expendable conductivity temperature depth profiler.

\section{Competing interests}

The authors declare that they have no competing interests.

\section{Authors' contributions}

YY, TI, MS, and SW proposed the topic and conceived and designed the study. YY, TI, MS, SW, HS, NU, YM, ST, MF, and TY carried out the observations and analyzed the data. YY, TI, MS, SW, HS, NU, YM, ST, MF, TY, MM, and AA helped in interpreting the data and approved the final manuscript.

\section{Acknowledgements}

We thank the Geospatial Information Authority of Japan for providing us with the GPS data from the terrestrial transponders for the kinematic GPS analysis and for releasing the daily coordinates of the sites on the GSI's website. We greatly thank 
Professor Keiichi Tadokoro for providing us with Nagoya University's seafloor geodetic observations. We also thank Oscar L. Colombo of the NASA Goddard Space Flight Center for providing us with the kinematic GPS software IT (Interferometric Translocation) (Colombo et al. 2000). Many among the staff of the Hydrographic and Oceanographic Department of the Japan Coast Guard, including the crew of the SNs Meiyo and Kaiyo, have supported our observations and data analyses. Comments from anonymous reviewers have improved our manuscript. Some figures were produced using the GMT software (Wessel and Smith 1991). Our article is in the science section: 4) solid earth sciences.

\section{Author details}

${ }^{1}$ Hydrographic and Oceanographic Department, Japan Coast Guard, 2-5-18 Aomi, Koto-ku, Tokyo 135-0064, Japan. ${ }^{2}$ National Research Institute for Earth Science and Disaster Prevention, 3-1 Tennodai, Tsukuba, Ibaraki 305-0006, Japan. ${ }^{3}$ Institute of Industrial Science, University of Tokyo, 4-6-1 Komaba, Meguro-ku, Tokyo 153-8505, Japan.

Received: 24 October 2014 Accepted: 6 April 2015

Published online: 02 May 2015

\section{References}

Altamimi Z, Collilieux X, Legrand J, Garayt B, Boucher C (2007) ITRF2005: a new release of the International Terrestrial Reference Frame based on time series of station positions and Earth Orientation Parameters. J Geophys Res 112:B09401, doi:10.1029/2007JB004949

Ando M (1975) Source mechanism and tectonic significance of historical earthquakes along the Nankai Trough, Japan. Tectonophysics 27:119-140, doi:10.1016/0040-1951(75)90102-X

Asada A, Yabuki T (2001) Centimeter-level positioning on the seafloor. Proc Jpn Acad Ser B 77:7-12

Baba T, Cummins PR (2005) Contiguous rupture areas of two Nankai Trough earthquakes revealed by high-resolution tsunami waveform inversion. Geophys Res Lett 32:L083005, doi:10.1029/2004GL022320

Bangs NLB, Gulick SPS, Shipley TH (2006) Seamount subduction erosion in the Nankai Trough and its potential impact on the seismogenic zone. Geology 34:701-704, doi:10.1130/G22451.1

Colombo OL, Evans AG, Vigo-Aguiar MI, Ferrandiz JM, Benjamin JJ (2000) Longbaseline (>1000 km), sub-decimeter kinematic positioning of buoys at sea, with potential application to deep sea studies. Proc ION GPS 2000:1476-1484

Central Disaster Management Council of the Japanese Government (2013) http:// www.bousai.go.jp/jishin/nankai/taisaku/pdf/1_1.pdf (in Japanese).

DeMets C, Gordon RG, Argus DF, Stein S (1994) Effect of recent revisions to the geomagnetic reversal time scale on estimates of current plate motions. Geophys Res Lett 21:2191-2194, doi:10.1029/94GL02118

Dominguez S, Malavieille J, Lallemand SE (2000) Deformation of accretionary wedges in response to seamount subduction: insights from sandbox experiments. Tectonics 19:182-196, doi:10.1029/1999TC900055

Duan B (2012) Dynamic rupture of the 2011 Mw 9.0 Tohoku-Oki earthquake: roles of a possible subducting seamount. J Geophys Res 117:B05311, doi:10.1029/2011JB009124

Fujita M, Ishikawa T, Mochizuki M, Sato M, Toyama S, Katayama M, Matsumoto Y, Yabuki T, Asada A, Colombo OL (2006) GPS/acoustic seafloor geodetic observation: method of data analysis and its application. Earth Planets Space 58:265-275, doi:10.1186/BF03351923

Ito T, Hashimoto M (2004) Spatiotemporal distribution of interplate coupling in southwest Japan from inversion of geodetic data. J Geophys Res 109:B02315, doi:10.1029/2002JB002358

Kido M, Fujimoto H, Miura S, Osada Y, Tsuka K, Tabei T (2006) Seafloor displacement at Kumano-nada caused by the 2004 off Kii Peninsula earthquakes, detected through repeated GPS/acoustic surveys. Earth Planets Space 58:911-915

Kido M, Osada Y, Fujimoto H, Hino R, Ito Y (2011) Trench-normal variation in observed seafloor displacements associated with the 2011 Tohoku-Oki earthquake. Geophys Res Lett 38:L24303, doi:10.1029/2011GL050057

Kodaira S, Takahashi N, Nakanishi A, Miura S, Kaneda Y (2000) Subducted seamount imaged in the rupture zone of the 1946 Nankaido earthquake. Science 289:104-106, doi:10.1126/science.289.5476.104

Kodaira S, Nakanishi A, Park J-O, Ito A, Tsuru T, Kaneda Y (2003) Cyclic ridge subduction at an inter-plate locked zone off central Japan. Geophys Res Lett 30:6, doi:10.1029/2002GL016595
Loveless JP, Meade BP (2010) Geodetic imaging of plate motions, slip rates, and partitioning of deformation in Japan. J Geophys Res 115:B02410, doi:10.1029/2008JB006248

Matsumoto Y, Fujita M, Ishikawa T, Mochizuki M, Yabuki T, Asada A (2006) Undersea co-seismic crustal movements associated with the 2005 Off Miyagi Prefecture Earthquake detected by GPS/acoustic seafloor geodetic observation. Earth Planets Space 58:1573-1576, doi:10.1186/BF03352663

Matsumoto Y, Fujita M, Ishikawa T (2008) Development of multi-epoch method for determining seafloor station position (in Japanese). Report of Hydrographic and Oceanographic Researches 26:16-22

Mochizuki K, Yamada T, Shinohara M, Yamanaka Y, Kanazawa T (2008) Weak interplate coupling by seamounts and repeating $M \sim 7$ earthquakes. Science 321:1194-1197, doi:10.1126/science. 1160250

Nishimura S, Hashimoto M (2006) A model with rigid rotations and slip deficits for the GPS-derived velocity field in southwest Japan. Tectonophysics 421:187-207, doi:10.1016/j.tecto.2006.04.017

Park J-O, Tsuru GT, Kodaira S, Cummins PR, Kaneda Y (2002) Splay fault branching along the Nankai subduction zone. Science 297:1157-1160, doi:10.1126/science.1074111

Park J-O, Moore GF, Tsuru T, Kodaira S, Kaneda Y (2003) A subducted oceanic ridge influencing the Nankai megathrust earthquake rupture. Earth and Planet Sci Let 217:77-84, doi:10.1016/S0012-821X(03)00553-3

Ranero CR, von Huene R (2000) Subduction erosion along the Middle America convergent margin. Nature 404:748-752, doi:10.1038/35008046

Sagiya T (1999) Interplate coupling in the Tokai district, central Japan, deduced from continuous GPS data. Geophys Res Lett 26:2315-2318, doi:10.1029/1999GL900511

Sagiya T, Thacher W (1999) Coseismic slip resolution along a plate boundary megathrust: the Nankai Trough, southwest Japan. J Geophys Res 104(B1):1111-1129, doi:10.1029/98JB02644

Sagiya T, Miyazaki S, Tada T (2000) Continuous GPS array and present-day crusta deformation of Japan. Pure Appl Geophys 157:2303-2322, doi:10.1007/PL00022507

Sato M, Ishikawa T, Ujihara N, Yoshida S, Fujita M, Mochizuki M, Asada A (2011a) Displacement above the hypocenter of the 2011 Tohoku-oki earthquake. Science 332:1395, doi:10.1126/science.1207401

Sato M, Saito H, Ishikawa T, Matsumoto Y, Fujita M, Mochizuki M, Asada A (2011b) Restoration of interplate locking after the 2005 Off-Miyagi prefecture earthquake, detected by GPS/acoustic seafloor geodetic observation. Geophys Res Lett 38:L01312, doi:10.1029/2010GL045689

Sato M, Fujita M, Matsumoto Y, Saito H, Ishikawa T, Asakura T (2013a) Improvement of GPS/acoustic seafloor positioning precision through controlling the ship's track line. J Geod 87:825-842, doi:10.1007/s00190-013-0649-9

Sato M, Fujita M, Matsumoto Y, Ishikawa T, Saito H, Mochizuki M, Asada A (2013b) Interplate coupling off northeastern Japan before the 2011 Tohoku-oki earthquake, inferred from seafloor geodetic data. J Geophys Res 118:1-10, doi:10.1002/jgrb.50275

Seno T, Stein S, Gripp AE (1993) A model for the motion of the Philippine Sea plate consistent with NUVEL-1 and geological data. J Geophys Res 98(B10):17941-17948

Spiess FN, Chadwell CD, Hildebrand JA, Young LE, Purcell GH Jr, Dragert H (1998) Precise GPS/acoustic positioning of seafloor reference points for tectonic studies. Phys Earth and Planet Inter 108:101-112, doi:10.1016/S0031-9201(98)00089-2

Tadokoro K, Ikuta R, Watanabe T, Ando M, Okuda T, Nagai S, Yasuda K, Sakata T (2012) Interseismic seafloor crustal deformation immediately above the source region of anticipated megathrust earthquake along the Nankai Trough, Japan. Geophys Res Lett 39:L10306, doi:10.1029/2012GL051696

Tanioka Y, Satake K (2001) Detailed coseismic slip distribution of the 1944 Tonankai Earthquake estimated from tsunami waveforms. Geophys Res Lett 28:1075-1078, doi:10.1029/2000GL012284

Watanabe S, Sato M, Fujita M, Ishikawa T, Yokota Y, Ujihara N, Asada A (2014) Evidence of viscoelastic deformation following the 2011 Tohoku-oki earthquake revealed from seafloor geodetic observation. Geophys Res Lett 41:5789-5796, doi:10.1002/2014GL061134

Wessel P, Smith WHF (1991) Free software helps map and display data. Eos Trans AGU 72:441, doi:10.1029/90EO00319

Yang H, Liu Y, Lin J (2012) Effects of subducted seamounts on megathrust earthquake nucleation and rupture propagation. Geophys Res Lett 39:L24302, doi:10.1002/2012GL053892 
Yang H, Liu Y, Lin J (2013) Geometrical effects of a subducted seamount on stopping megathrust ruptures. Geophys Res Lett 40:1-6, doi:10.1002/grl.50509

Yasuda K, Tadokoro K, Ikuta R, Watanabe T, Nagai S, Okuda T, Fujii C, Sayanagi K (2014) Interplate locking condition derived from seafloor geodetic data at the northernmost part of the Suruga Trough, Japan. Geophys Res Lett 41:5806-5812, doi:10.1002/2014GL060945

Yoshioka S, Matsuoka Y (2013) Interplate coupling along the Nankai Trough, southwest Japan, inferred from inversion analyses of GPS data: effects of subducting plate geometry and spacing of hypothetical ocean-bottom GPS stations. Tectonophysics 600:165-174, doi:10.1016/j.tecto.2013.01.023

Submit your manuscript to a SpringerOpen ${ }^{\circ}$ journal and benefit from:

- Convenient online submission

- Rigorous peer review

- Immediate publication on acceptance

- Open access: articles freely available online

- High visibility within the field

- Retaining the copyright to your article

Submit your next manuscript at $\gg$ springeropen.com 